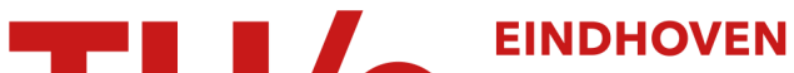 UNIVERSITY OF TECHNOLOGY
}

\section{Direct injection of diesel-butane blends in a heavy duty engine}

\section{Citation for published version (APA):}

Leermakers, C. A. J., van den Berge, B., Luijten, C. C. M., Goey, de, L. P. H., \& Jaasma, S. A. M. (2011). Direct injection of diesel-butane blends in a heavy duty engine. SAE International Journal of Fuels and Lubricants, 4(2), 179-187. [2011-01-2400]. https://doi.org/10.4271/2011-01-2400

DOI:

10.4271/2011-01-2400

Document status and date:

Published: 01/01/2011

\section{Document Version:}

Publisher's PDF, also known as Version of Record (includes final page, issue and volume numbers)

\section{Please check the document version of this publication:}

- A submitted manuscript is the version of the article upon submission and before peer-review. There can be important differences between the submitted version and the official published version of record. People interested in the research are advised to contact the author for the final version of the publication, or visit the $\mathrm{DOI}$ to the publisher's website.

- The final author version and the galley proof are versions of the publication after peer review.

- The final published version features the final layout of the paper including the volume, issue and page numbers.

Link to publication

\section{General rights}

Copyright and moral rights for the publications made accessible in the public portal are retained by the authors and/or other copyright owners and it is a condition of accessing publications that users recognise and abide by the legal requirements associated with these rights.

- Users may download and print one copy of any publication from the public portal for the purpose of private study or research.

- You may not further distribute the material or use it for any profit-making activity or commercial gain

- You may freely distribute the URL identifying the publication in the public portal.

If the publication is distributed under the terms of Article $25 \mathrm{fa}$ of the Dutch Copyright Act, indicated by the "Taverne" license above, please follow below link for the End User Agreement:

www.tue.nl/taverne

Take down policy

If you believe that this document breaches copyright please contact us at:

openaccess@tue.nl

providing details and we will investigate your claim. 


\title{
Direct Injection of Diesel-Butane Blends in a Heavy Duty Engine
}

\author{
C.A.J. Leermakers, B. Van den Berge, C.C.M. Luijten and L.P.H. de Goey \\ Eindhoven University of Technology
}

S. Jaasma

Vialle Alternative Fuel Systems

\begin{abstract}
Increasing fuel prices keep bringing attention to alternative, cheaper fuels. Liquefied Petroleum Gas (LPG) has been well known for decades as an alternative fuel for spark ignition (SI) passenger cars. More recently, aftermarket LPG systems were also introduced to Heavy Duty transport vehicles. These (port fuel) systems either vaporize the liquid fuel and then mix it with intake air, or inject fuel into the engine's intake ports.
\end{abstract}

While this concept offers significant fuel cost reductions, for aftermarket certification and large-scale OEM use some concerns are present. Unburned hydrocarbons (UHC) and carbon monoxide (CO) emissions are known to be high because of premixed charge getting trapped into crevices and possibly being blown through during valve-overlap. Apart from the higher emission levels, this also limits fuel efficiency and therefore cost savings.

Direct injection of LPG offers a solution to the aforementioned concerns by directing the fuel to the desired areas of the combustion chamber. To investigate the potential of this concept, diesel has been blended with liquid butane, in different ratios. These blends were directly injected into a heavy duty test engine, using a standard common rail injector.

Results show that even at low loads, a butane mass fraction of one-third can be used without negatively affecting emissions. For direct injected butane, hydrocarbon emissions were found to be an order of magnitude lower than when port fuel injected butane is used. At this butane fraction, smoke emissions decrease by $50 \%$. Because a high combustion efficiency is retained, fuel cost savings can be significant. At higher loads, an even higher butane mass fraction can be used, further enhancing the fuel cost saving potential.

\section{INTRODUCTION}

Due to increasingly stringent emission standards, engine development is forced to invest heavily in research for advanced combustion and exhaust aftertreatment systems. The exotic materials used in aftertreatment are boosting production costs; therefore reduction of in-cylinder emission formation is needed. Furthermore, rising fuel cost and a focus on reduction of greenhouse gases drive developments towards a better efficiency of the internal combustion engine.

LPG (Liquefied Petroleum Gas) has for long been used as an automotive fuel in light vehicles like private cars and taxies. LPG is a waste product of the refining process of fossil fuels, resulting in a low fuel price [1]]. LPG consists of butane and propane, and depending on fuel grade and region around the world, LPG ranges from nearly pure propane $(95 \%)$ to nearly all butane $(>80 \%)$. In the Netherlands, LPG is widely available and due to tax benefits it is attractively priced compared to, for example, diesel.

Recently, LPG supply systems in diesel engines have attracted considerable attention due to the requirement of more powerful engines in, for example, urban buses [2]. LPG can be used in heavy-duty diesel engines combining port fuel injection of LPG and a direct injection of diesel. Dual fuel engines equipped with a port fuel injection (PFI) system typically suffer from the problems of poor brake thermal efficiency and high $\mathrm{HC}$ emissions, particularly at low loads 
[2]. According to Poonia et al [3], $\mathrm{HC}$ emissions can be lowered and brake thermal efficiency can be increased using hot Exhaust Gas Recirculation (EGR), resulting in a higher intake temperature.

All of the aforementioned investigations concluded that using port fuel injection of LPG, operational costs savings are possible. However, these savings were shown to come with a significant emissions penalty. A possible workaround to the latter problem could be the combustion of a premixed blend. The goal of this research is to explore whether the use of a premixed fuel can neutralize the emission penalty of PFI LPG, while maintaining the operational cost savings. This might be extended to an operational costs saving combined with a simultaneous emission benefit.

Therefore, in this investigation a premixed butane-diesel blend is directly injected, using only one fuel system, to determine the influence of butane on conventional diesel combustion. For hardware safety reasons a diesel-butane blend is used, rather than a diesel-LPG blend. When using real LPG, the propane in the blend would lead to a higher vapor pressure, which is more hard to control on the experimental set-up and therefore would present the risk of over pressure in the injector's fuel supply line.

Using a dual fuel PFI system, Jian et al [2] found a significant reduction in soot emissions, but an increase in $\mathrm{HC}, \mathrm{NO}_{\mathrm{x}}$ and $\mathrm{CO}$ emissions for the same power output. Donghui et al [1] used a premixed LPG/diesel blend for a directly injected diesel engine and found longer ignition delays. This resulted in a better premixing of the fuel with air, a reduction in soot emissions, a small increase in $\mathrm{HC}$ emissions and slightly higher fuel consumption. As a reason for lower soot production with DI premixed blends, Cao and coworkers [4] suggest better premixing of the fuel with air due to flash boiling in the injected spray when LPG is added.

The key issue for the direct injection strategy of premixed blends is finding the right diesel-butane content at different operating conditions. A low butane content may slightly reduce costs but have no effect on soot emissions. Higher butane content can further reduce costs and emissions; however in-cylinder pressure can increase rapidly and damage the engine [1]. When engine load is low, higher butane content can influence combustion phasing, performance and emissions.

Apart from the changing combustion phasing and emissions, the change in fuel consumption plays an important role. A diesel-butane blend contains less energy per volume, resulting in higher fuel consumption in terms of $\mathrm{L} / \mathrm{km}[1,4]$. With the right amount of butane in the blend this fuel penalty might be compensated by lower fuel costs.

\section{EXPERIMENTS}

\section{EXPERIMENTAL APPARATUS}

Over the last years, at Eindhoven University of Technology a versatile test engine setup, referred to as CYCLOPS, was developed for testing of fuels, engine hardware and combustion concepts. This engine set-up is described in detail by Leermakers et al. [ [ ] and summarized below, with the changes made for the current investigation.

The CYCLOPS is a dedicated engine test rig, see Table 1, based on a DAF XE $355 \mathrm{C}$ engine. Cylinders 4 through 6 of this inline 6 cylinder HDDI engine operate under the stock DAF engine control unit and together with a water-cooled, eddy-current Schenck W450 dynamometer they are merely used to control the crankshaft rotational speed of the test cylinder, i.e. cylinder 1. Apart from the mutual cam- and crankshaft and the lubrication and coolant circuits, this test cylinder operates autonomously from the propelling cylinders. Standalone air, EGR and fuel circuits have been designed for maximum flexibility, as is discussed below.

Table 1. Cyclops test setup specifications

\begin{tabular}{|l|l|}
\hline Base Engine & 6 cylinder HDDI diesel \\
\hline Cylinders & 1 Test cylinder \\
\hline Bore $[\mathrm{mm}]$ & 130 \\
\hline Stroke $[\mathrm{mm}]$ & 158 \\
\hline Compression ratio & 14.9 (original 17.0) \\
\hline
\end{tabular}

Fed by an air compressor, the intake air pressure of the test cylinder can be boosted up to 5 bar. Non-firing cylinders 2 and 3 function as EGR pump cylinders, see Figure 1, the purpose of which is to generate adequate EGR flow, even at 5 bar charge pressure and recirculation levels in excess of $70 \%$. The EGR flow can be cooled both up- and downstream of the pump cylinders. Surge tanks, to dampen oscillations and ensure adequate mixing of fresh air and EGR, and pressure relief valves, to guard for excessive pressure in the circuit, were also included in the design. Please note that in this investigation no EGR is used.

For measuring gaseous exhaust emissions, a Horiba Mexa 7100 DEGR emission measurement system is used. Exhaust smoke levels are measured using an AVL 415 smoke-meter. All quasi steady-state engine data, together with air and fuel flows and emission levels are recorded by means of an inhouse data acquisition system (TUeDACS). A SMETEC Combi data acquisition system is used to record and process crank angle resolved data. 


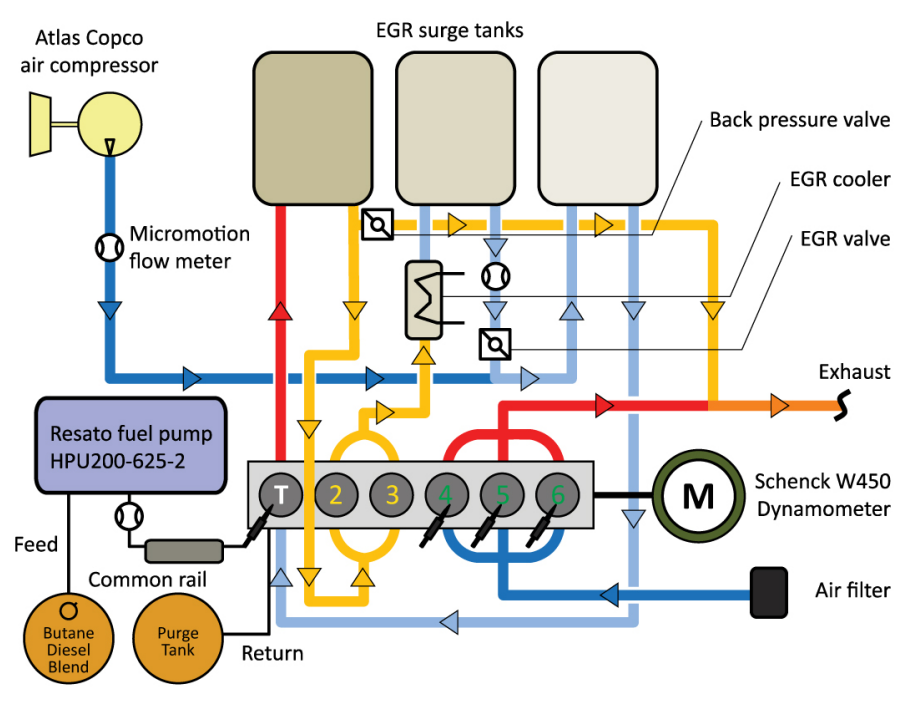

Figure 1. Schematic of experimental setup CYCLOPS: modified DAF engine using separate fuel, air and EGR systems for one dedicated test cylinder

For the present measurements, the fuel system was adjusted to inject pre-mixed diesel-butane blends directly into cylinder 1. A standard LPG tank with a built-in low pressure fuel pump provides the blend at 5 bar over the vapor pressure to the high pressure pump. Fuel density is monitored to be confident that the fuel blends do not partially or fully separate within the fuel system. This double-acting air-driven Resato HPU200-625-2 pump can deliver a fuel pressure up to 4200 bar, but for the present investigation the fuel pressure is set to 1500 bar. An accumulator is placed near $(\sim 0.2 \mathrm{~m})$ the fuel injector to mimic the volume of a typical common rail and dampen pressure fluctuations originating from the pump. The prototype common rail injector used has a nozzle with 8 holes of $0.151 \mathrm{~mm}$ diameter and a cone angle of 153 degrees. The injector leak flow is captured in a surge tank. This tank will reach a pressure of 10 bar maximum, because this is the highest vapor pressure of the blends at $90^{\circ} \mathrm{C}$, which is the temperature of the cylinder head at the leak flow of the injector.

To test direct injection back to back with port fuel injected butane, the setup is also equipped with a port fuel injection (PFI) system. In this case, the low pressure pump in the LPG tank is directly coupled to this liquid fuel PFI injector.

\section{FUELS AND OPERATING CONDITIONS}

To test the viability of direct injection of a diesel mixed with LPG, a standard EN590 diesel fuel is compared to three butane-diesel blends. These blends are called But14, But33, But50, after their respective mass percentages of butane in the blend. Butane is used instead of LPG, both to be certain of the blend composition and to limit blend vapor pressures for hardware safety reasons. Injector stability is guaranteed up to 10 bar back pressure, therefore the return pressure should not exceed this value. The blends have been chosen accordingly.

To calculate blend properties, data from Younglove []ㅡ and the DIPPR database [7] are used. Kalghatgi has given a relation in [ $[\overline{8}]$ to calculate the estimated Cetane number, based on the octane number of a low reactive fuel, such as LPG. Furthermore, Kalghatgi states that the Cetane number scales linearly with the molar fractions of the two fuels in the blend. The more butane is added to the fuel the less reactive the blend becomes. Note that the energy density per unit volume also decreases when the butane content is increased.

The maximum vapor pressure of the blends in the fuel line is calculated using Raoult's law [9], which states that the vapor pressure of an ideal solution equals the sum of the vapor pressures of each chemical component times its mole fraction in the liquid phase. In this case the vapor pressure of diesel can be neglected.

Besides testing diesel and three diesel-butane blends, as a reference also port fuel injected pure butane is investigated, combined with direct injected diesel. In these cases, the same mass percentages of butane of the total injected fuel are used. In Table 2 all further properties of the blends, except for the estimated cetane number (ECN), are calculated on a mass fraction base, since the content of butane in the blend is given in mass fractions.

Table 2. Fuel properties of diesel-butane blends

\begin{tabular}{|l|l|l|l|l|l|}
\hline & Diesel & But14 & But33 & But50 & Butane \\
\hline $\begin{array}{l}\text { wt\% } \\
\text { Butane }\end{array}$ & 0 & 14 & 33 & 50 & 100 \\
\hline $\begin{array}{l}\text { vol\% } \\
\text { Butane }\end{array}$ & 0 & 20 & 43 & 60 & 100 \\
\hline $\begin{array}{l}\text { LHV } \\
{[\mathrm{MJ} / \mathrm{kg}]}\end{array}$ & 43.00 & 43.39 & 43.92 & 44.38 & 45.75 \\
\hline $\begin{array}{l}\text { LHV } \\
{[\mathrm{MJ} / \mathrm{L}]}\end{array}$ & 37.30 & 35.27 & 32.96 & 31.23 & 27.70 \\
\hline $\begin{array}{l}\text { Density } \\
{[\mathrm{kg} / \mathrm{m} 3]}\end{array}$ & 830 & 790 & 757 & 690 & 550 \\
\hline $\begin{array}{l}\text { ECN } \\
{[-]}\end{array}$ & 55.90 & 41.90 & 31.40 & 25.50 & 16.38 \\
\hline $\begin{array}{l}\text { Psat [bar] } \\
(@ 365 \mathrm{~K})\end{array}$ & negl. & 4.50 & 7.98 & 9.88 & 12.9 \\
\hline
\end{tabular}

A load of 8 bar gross IMEP was selected for this test of premixed diesel-butane blends. This is approximately one third of rated power and is considered a reasonable approximation of average load. A second 12 bar IMEP load (ca. $50 \%$ of rated power) is also tested, to shortly check the behavior at higher loads. Loads are maintained constant by a longer actuation duration when more butane is added to the blend. In practice this can be realized by enlarging throttle pedal position, creating a longer actuation duration of the 
injector. Intake pressure is chosen such that lambda is kept constant at approximately 1.3 to see significant differences in smoke emissions between the blends.

Three Starts of Actuation (SOAs) are used for each operating point. These are chosen such, that they result in a CA50 of 5, 7.5 and 10 degrees aTDC for the Diesel case. The injection timing is kept constant for all blends, to reveal clear differences in combustion phasing between the blends, which would be representative for after-market in-vehicle application. After a warm-up procedure the operating conditions are set to the desired values with an operating engine speed of 1200 RPM. The low pressure pump is set to 5 bar over the saturation pressure of the blend and the direct injection pump is set to 1500 bar. To sum up:

- $1200 \mathrm{rpm}$

\section{- No EGR}

- 8 bar gross IMEP: Inlet pressure 1 bar, SOA $-12,-9,-6$ degr ATDC

- 12 bar gross IMEP: Inlet pressure 1.5 bar, SOA $-14,-12$, -9 degr ATDC

- Approximately constant Lambda $1.3( \pm 8 \%)$

- 1500 bar DI pressure

For more information on the experimental setup and measurement procedure, the reader is referred to [5] .

\section{RESULTS AND DISCUSSION}

Below, mainly results for the lower ( 8 bar) load point are given. Where applicable, results for the 12 bar load point are also presented. The comparison to port fuel injected butane is made only for the most interesting quantities, i.e. $\mathrm{HC}$ and $\mathrm{NO}_{\mathrm{x}}$ emissions.

\section{COMBUSTION PHASING}

The fuels under investigation are characterized by their ignition delay due to the lower reactivity of butane. With a longer ignition delay the time to pre-mix is elongated and with the help of local leaner mixtures emissions can be reduced. For a fixed start of actuation (SOA), due to the lower reactivity of butane the ignition delay is extended with increasing butane content, meaning a retarded start of combustion, see Figure 2. The difference between diesel and But14 is negligible, and for But33 less than 1 deg CA, but for But50 one can see that the lower reactivity influences the ignition delay with an extension of more than 2 deg CA.

Although combustion starts later, end of combustion is still closer to TDC when more butane is added. This shorter burn duration (BD) can be related to the more rapidly vaporizing butane. This also means that due to the shorter burn duration,
CA50 (crank angle where 50 percent of the injected mass is burned) is placed slightly closer to TDC, resulting in higher peak temperatures, see the Emissions section below. With a shorter BD the timing of combustion can be controlled more easily, benefitting the efficiency. The downside of the shorter $\mathrm{BD}$ can be a higher pressure rise rate which can result in engine hardware damage and exceeding of the engine's noise limits. It is therefore suggested to use a maximum mass percentage of $33 \%$ butane, if injection timing is not adjusted. In this case, pressure rise rates are comparable to the dieselonly case (not shown).

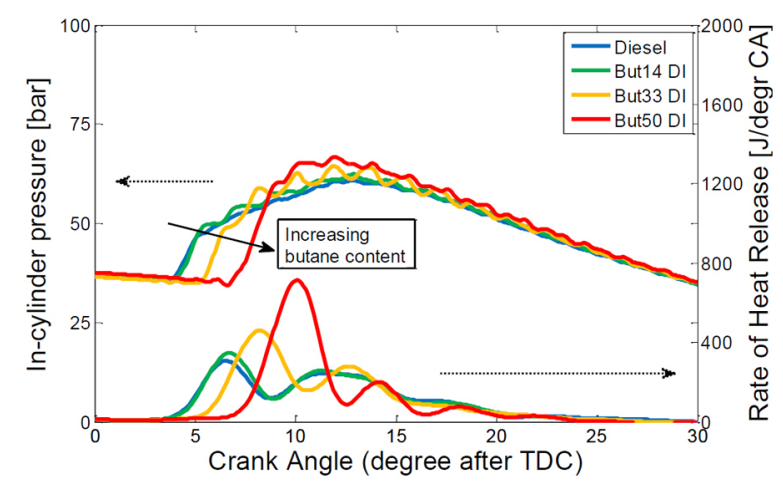

Figure 2. Single shot in-cylinder pressure and heat release rate for diesel and DI diesel-butane blends, 8 bar gross IMEP, SOA-6 $\operatorname{deg} C A$

At higher loads the difference in combustion phasing between the blends can be neglected. At these loads it is believed that pressure and temperature are dominant in combustion phasing compared to fuel composition $[\underline{5}, \underline{10}]$. For that reason no figures of these measurements are shown here. When using port injected butane, the same phenomena are observed, see Figure 3. However, in this case the phenomena seem to be more linearly proportional to the amount of butane.

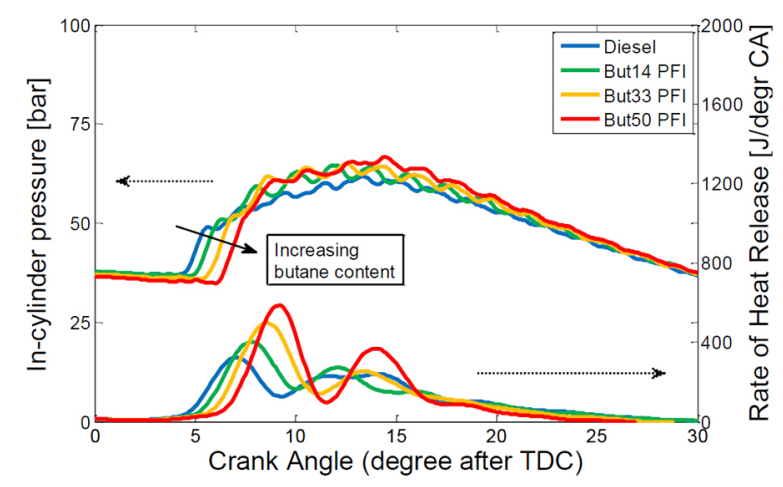

Figure 3. Single shot in-cylinder pressure and heat release rate for diesel and PFI butane, 8 bar gross IMEP, SOA-6 degCA 


\section{EMISSIONS}

\section{Unburned Hydrocarbon Emissions}

The main objective of testing direct injection of butane has been to compare its unburned hydrocarbon emissions with those of port fueled butane. Figure 4 shows the hydrocarbon emissions for the 8 bar load point. For the PFI measurements, the $\mathrm{HC}$ emissions are nearly proportional to the amount of port injected fuel. This can easily be associated with a fixed volume of uncombusted charge. The crevice volume does not allow for combustion to complete and therefore any fuel trapped in this volume results in unburned hydrocarbons.

For direct injected butane, hydrocarbon emissions are an order of magnitude lower than with PFI. Up to $33 \mathrm{wt} \%$ butane, no differences are seen compared to diesel-only. For the $50 \mathrm{wt} \%$ DI points, although much lower than all PFI points, hydrocarbon emissions are slightly raised. Donghui et al. [1] assume that the aforementioned crevice phenomenon might also exist with direct injected butane. However, this is unlikely because of the shortage of time for the fuel to reach the crevices when injecting directly at 5 degrees CA bTDC. A more likely reason to relate higher $\mathrm{HC}$ emissions, for high butane fraction DI, are local high air fuel ratio spots due to the better pre-mixing, possibly resulting in local flame quenching ("overleaning").

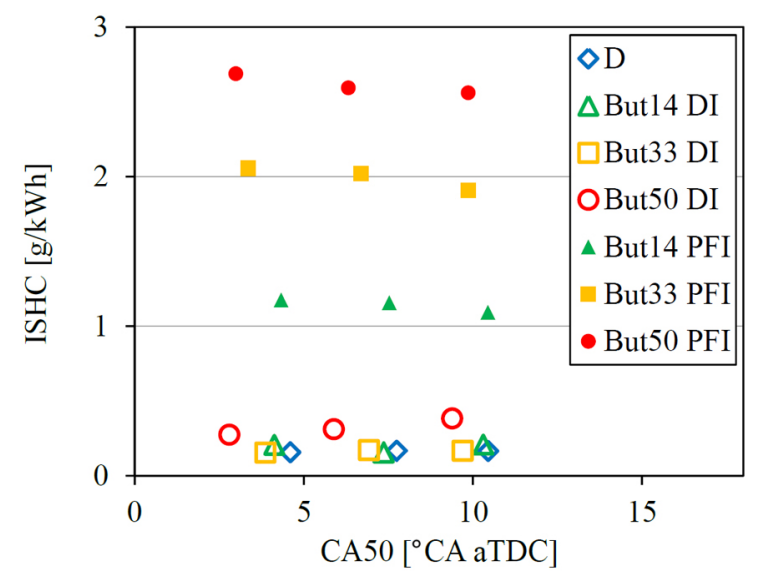

Figure 4. Unburned hydrocarbon emissions for diesel, DI diesel-butane blends, and PFI butane, 8 bar gross IMEP

For the 12 bar load case (Figure 5), the PFI points again show a trend proportional to the amount of port fueled butane. Furthermore, the DI hydrocarbon emissions are again much lower than the port fueled butane points. For this higher load, even the $50 \mathrm{wt} \%$ DI point's HC emissions are not raised compared to diesel-only. This is assumed to originate from the higher load, higher temperature combustion and associated full oxidation.

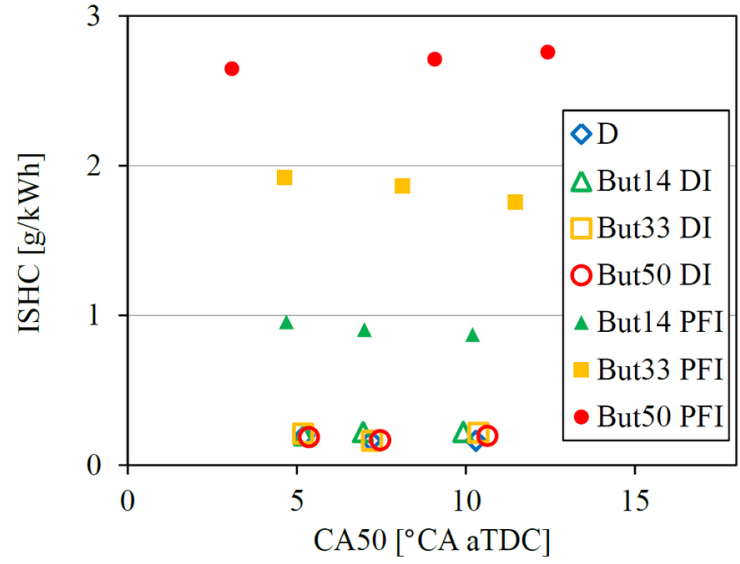

Figure 5. Unburned hydrocarbon emissions for diesel, DI diesel-butane blends, and PFI butane, 12 bar gross IMEP

From the above results one can conclude that the direct injection of butane is a very promising concept when it comes to hydrocarbon emissions. Apart from a possible improvement in fuel efficiency and therefore cost savings, the lower emissions levels open the door for aftermarket certification and large-scale OEM use of LPG in heavy duty applications.

\section{Carbon Monoxide Emissions}

As discussed above, the operating points are chosen such that significant differences should be observable for Smoke emissions. The drawback of this relatively rich charge is that carbon monoxide emissions are quite high, see Figure 6. For the low load points under investigation, even for the diesel only, $\mathrm{CO}$ emissions are much higher than generally experienced with diesel engines. From Figure 6 we also see that for the two lower butane blends, $\mathrm{CO}$ levels are similar to those of diesel. The blend containing most butane, however, shows significantly lower emissions. One possible reason is flash vaporization; due to the high butane fraction, the liquid spray immediately "flashes" into vapor. This extremely rapid vaporization of butane in the blend could have the advantage of better pre-mixing with the air compared to regular diesel, certainly in combination with an extended ignition delay. Due to this possibly better premixing, local spots could become less rich and $\mathrm{CO}$ emissions could be reduced.

At the higher load, higher temperature operating points, even for the relatively rich charges, carbon monoxide levels are significantly lower than for the low load case. Figure 7 shows that differences between the blends are insignificant at these higher loads; the butane content does not seem to have a big influence on $\mathrm{CO}$ emissions. 


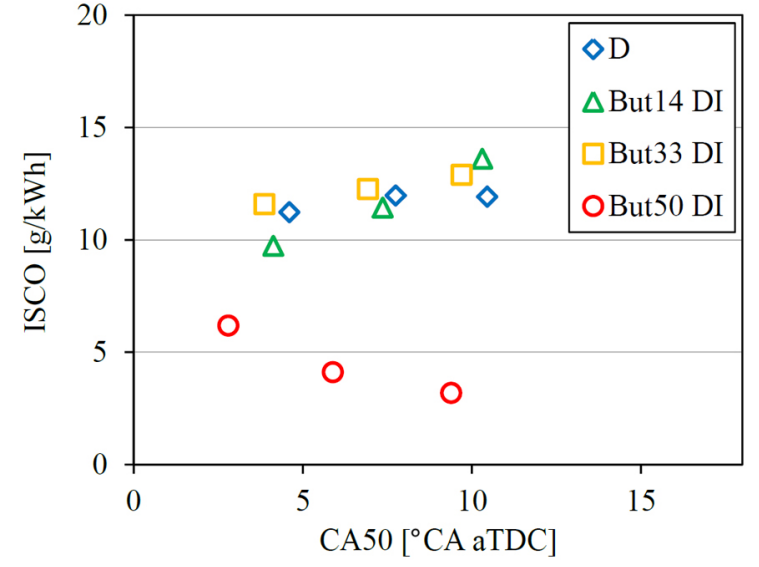

Figure 6. Carbon monoxide emissions for diesel and DI diesel-butane blends, 8 bar gross IMEP

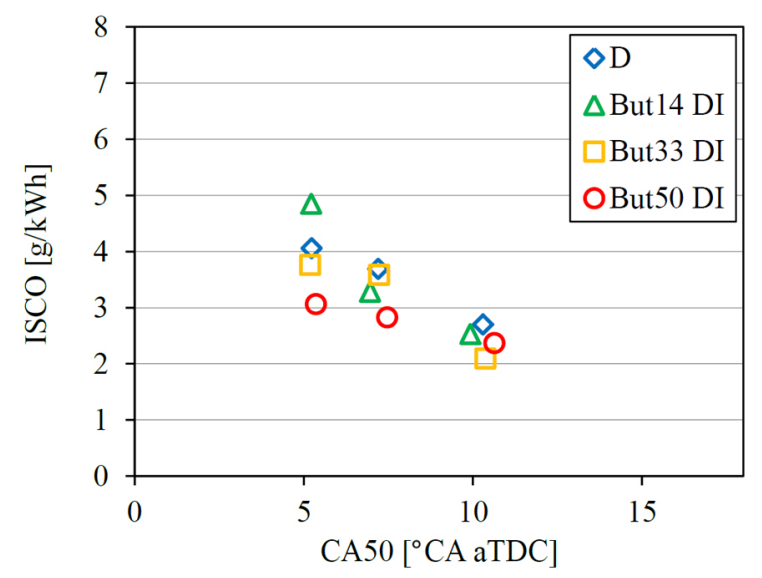

Figure 7. Carbon monoxide emissions for diesel and DI diesel-butane blends, 12 bar gross IMEP

\section{Nitrogen Oxide Emissions}

Since for these experiments no EGR was used, the first thing to note from Figure 8 is that all nitrogen oxide emissions levels are relatively high. Looking at the port fueled butane points, $\mathrm{NO}_{\mathrm{x}}$ levels increase with the amount of injected butane. This butane is believed to combust in a flame front, where high local temperatures give rise to $\mathrm{NO}_{\mathrm{x}}$ emissions. For the low butane content DI points, combustion is still thought to be diesel-like, with diffusion flamelets surrounding a hot fuel jet. Up to $33 \mathrm{wt} \%$ of DI butane, $\mathrm{NO}_{\mathrm{x}}$ levels are not changed significantly compared to diesel-only. Only for the largest DI butane amount, the same flash vaporization as mentioned above, could give the possibility of flame front propagation in the combustion chamber, and the associated higher $\mathrm{NO}_{\mathrm{x}}$ emissions.

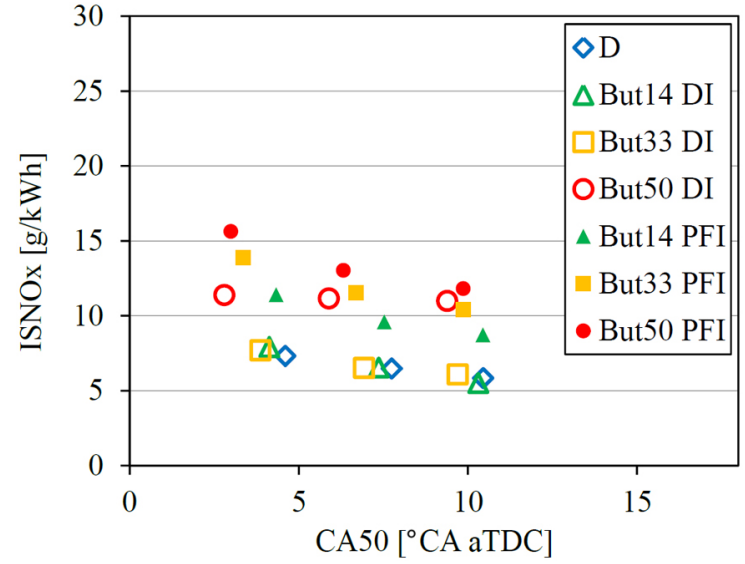

Figure 8. Nitrogen oxides emissions for diesel, DI dieselbutane blends, and PFI butane, 8 bar gross IMEP

For the higher load, as depicted in Figure 9, the port fueled butane points show the same trends as for the lower load. Again, the DI points show lower $\mathrm{NO}_{\mathrm{x}}$ emissions than the PFI points. Differences in $\mathrm{NO}_{\mathrm{x}}$ levels between the various DI blends are small. In contradiction to PFI of butane, with DI butane these are barely increased, which makes the latter concept again look promising. At the low load of 8 bar IMEP, $33 \mathrm{wt} \%$ of DI butane is allowed without a significant increase in $\mathrm{NO}_{\mathrm{x}}$ emissions, and at the 12 bar load this is even $50 \mathrm{wt} \%$. These are the same percentages that were found above for hydrocarbon emissions.

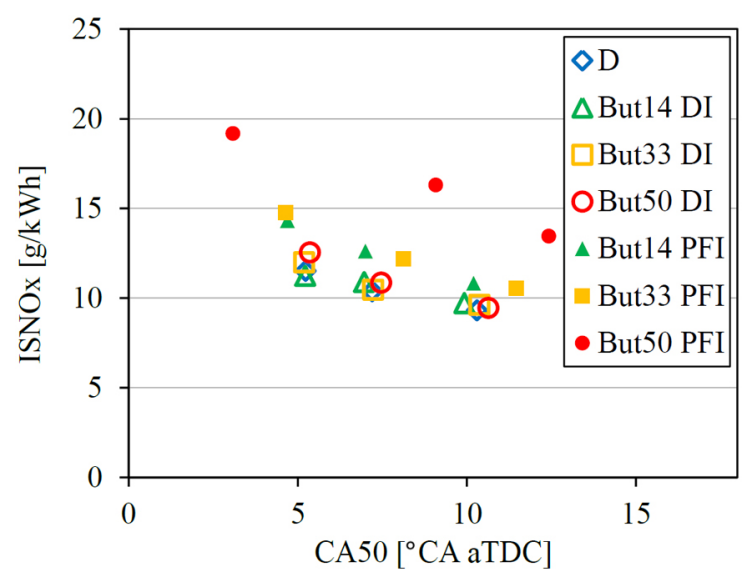

Figure 9. Nitrogen oxides emissions for diesel, DI dieselbutane blends, and PFI butane, 12 bar gross IMEP

\section{$\underline{\text { Smoke Emissions }}$}

Even though relatively rich operating points have been used, absolute smoke levels are still reasonably low, likely because of the short injection duration. Figure 10 shows that smoke emissions are even further reduced by adding butane to the blend. $33 \mathrm{wt} \%$ gives a 50 percent smoke reduction and $50 \mathrm{wt}$ $\%$ butane reduces smoke levels to zero. This can be explained 
by four reasons. First, it can be related to the rapidly vaporizing fuel, creating locally leaner mixtures. Another way butane can reduce local rich spots, and probably the most dominant reason for lower smoke emissions, is by its lower reactivity. Due to its lower cetane number, ignition delay is elongated, allowing more time for the fuel to mix with air.

Third, it is believed that butane in the blend will promote diesel atomization by enhancing gas perturbation with fluctuating pressure in the spray field and enhancing mixing with in-cylinder air to reduce the soot formation in the dieselfuel spray $[\underline{1}, \underline{4}]$. Next to the higher vapor pressure, another important aspect of butane is the molecular structure. Aliphatics, like butane, are known as less soot forming fuels, compared to aromatics present in diesel fuel. Although these four explanations are all reasonable to some extent, further research is needed to find out which one is dominant in reducing smoke levels.

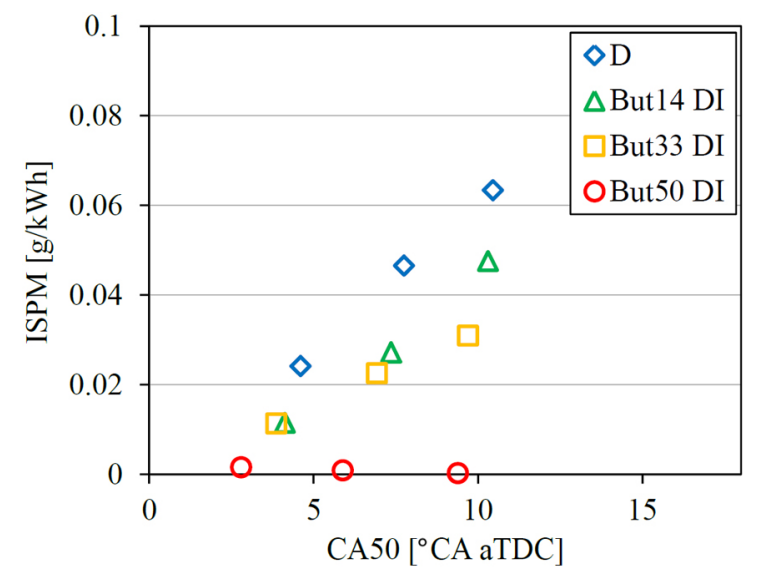

Figure 10. Smoke emissions for diesel and DI dieselbutane blends, 8 bar gross IMEP

Although lambda is kept similar to the experiments done at low loads, the smoke levels at the higher load point were too low to observe significant differences between the blends.

\section{FUEL CONSUMPTION AND EFFICIENCY}

Above it was shown that certain percentages of butane can be directly injected in a diesel engine, without an emission penalty. The main incentive of using butane as an alternative fuel is its lower price. To benefit from this price advantage, fuel consumption should not be negatively affected. Fuel consumption can be reported in several ways. Common practice in engine legislation is describing the indicated specific fuel mass consumption, see Figure 11. It appears that the fuel consumption in mass does not change much, even in favor of the $50 \mathrm{wt} \%$ butane fuel when it is compared to diesel, mostly because of the difference in energy density per unit mass (see Table 2).

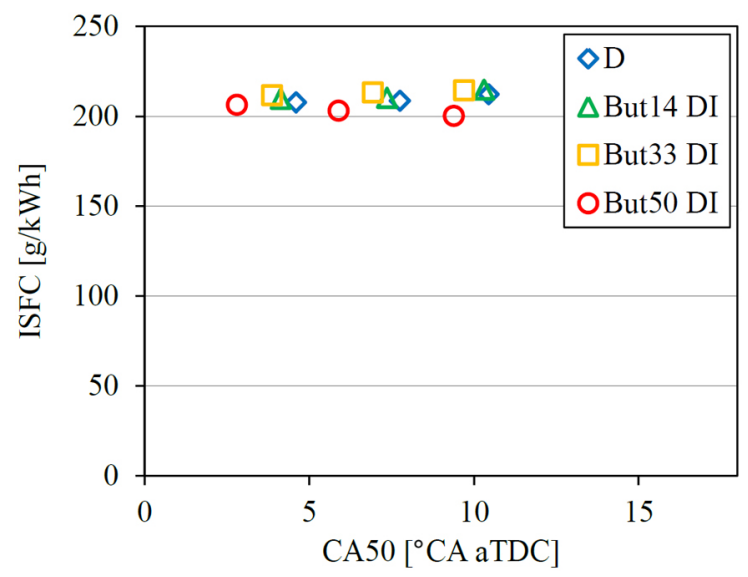

Figure 11. Specific fuel mass consumption for diesel and butane-diesel blends, 12 bar gross IMEP

This is confirmed by plotting the indicated fuel efficiency, relating power output to the total injected energy, see Figure 12. The differences in indicated efficiency are negligible. The differences in combustion phasing on one side and hydrocarbon and carbon monoxide emissions on the other side may be counterbalancing or just insignificantly small.

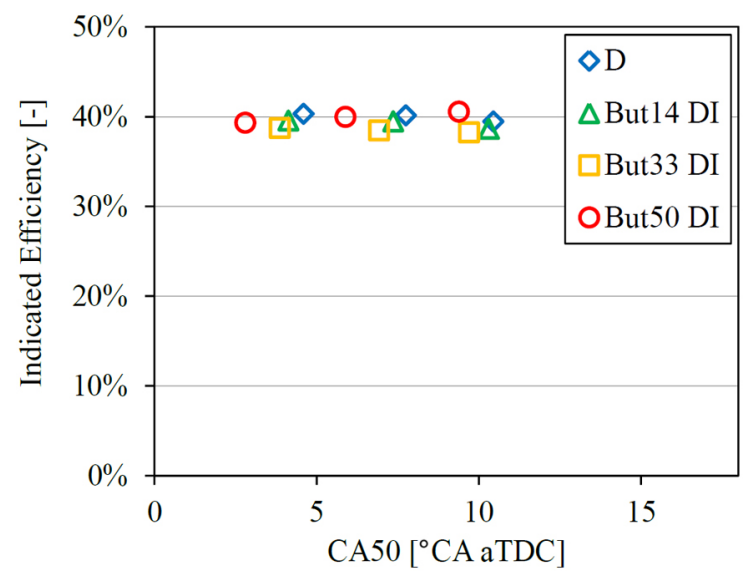

Figure 12. Indicated fuel efficiency for diesel and butane-diesel blends, 8 bar gross IMEP

Yet, as expected due to the lower energy density per unit volume, the largest differences are seen in fuel volume consumption. Although the indicated efficiency does not change significantly, the fuel penalty in liters raises with 10 to 20 percent, see Figure 13. The blends' densities are measured in the low pressure fuel circuit to calculate fuel volume consumption. It is noted that, because of the much lower CO production for the But50 blend, the fuel consumption is not fully proportional to the amount of butane. 


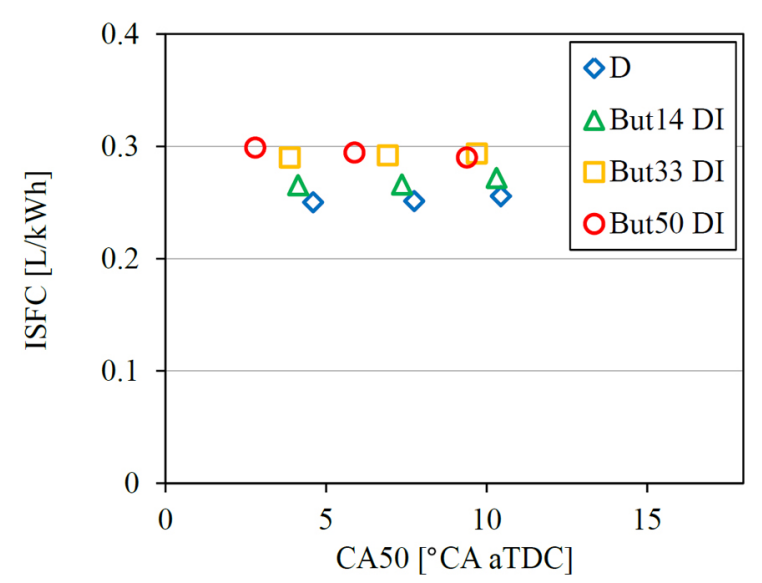

Figure 13. Indicated fuel volume consumption for diesel and butane-diesel blends, 8 bar gross IMEP

\section{FUEL COSTS}

Above it was demonstrated that up to $33 \mathrm{wt} \%$ of butane can be added to diesel without compromising emissions. However, fuel volume consumption is somewhat increased. To compute possible fuel cost savings, the average Dutch suggested retail prices for both diesel and LPG are taken, see Table 3. Here, the price of LPG is taken, because it includes applicable taxes and prices for the blends are calculated using their respective volume fractions.

Table 3. Fuel costs for diesel, LPG and the tested blends, 20 July 2011, The Netherlands. Note that LPG has not been tested and that as such, no fuel consumption data are available.

\begin{tabular}{|l|l|l|l|l|l|}
\hline & Diesel & LPG & But14 & But33 & But50 \\
\hline$€ / \mathrm{L}$ & 1.40 & 0.78 & 1.28 & 1.13 & 1.03 \\
\hline $\mathrm{L} / \mathrm{kWh}$ & 0.313 & & 0.332 & 0.362 & 0.361 \\
\hline$€ / \mathrm{kWh}$ & 0.440 & & 0.426 & 0.413 & 0.373 \\
\hline$\frac{€ / k W h_{\text {blend }}}{€ / k W h_{\text {diesel }}}$ & $100 \%$ & & $96.8 \%$ & $93.8 \%$ & $84.8 \%$ \\
\hline
\end{tabular}

Furthermore, for each of the blends, the fuel costs are calculated for the most efficient points measured with 8 bar IMEP. From the normalized costs, one can see that for the 33 $\mathrm{wt} \%$ best points, a six percent cost advantage can be achieved with current fuel prices. This best point has shown to simultaneously reduce smoke emissions by $50 \%$ without negatively affecting other emissions. For the higher 12 bar load point it was shown that $50 \mathrm{wt} \%$ of butane may be used, which can give even higher cost advantages. Obviously, cost savings will depend on pricing and taxation levels, which may greatly differ per country.

\section{OUTLOOK: LPG VERSUS BUTANE}

In the experiments reported here butane was used. When LPG would be used, containing a certain amount of propane, it is believed that due to the even lower reactivity of propane emissions can be reduced even more. Adding propane will lead to higher ignition delays, which will further enhance premixing. The downside of this shift in combustion phasing is that injection timing must be controlled in order not to harm efficiency. Note that the energy density per volume of propane is slightly lower than that of butane, so it will further increase volumetric fuel consumption to some extent.

The minimum Cetane Number of LPG is estimated at 12.5 (based on $70 \mathrm{vol} \%$ propane and $30 \mathrm{vol} \%$ butane), which is about 4 points lower than that of pure butane. When assuming But33 is the best fuel in the experiments reported here, using LPG the results could be influenced in a positive way, but the maximum fuel fraction of LPG in the blend will be lower. These hypothesized effects provide ample reason for more research. Such research should also address, amongst others, possible effects of a higher vapor pressure in the fuel line.

\section{CONCLUSION AND OUTLOOK}

The goal of this research was to explore whether a premixed fuel can neutralize the emission penalty of PFI LPG, while maintaining the operation cost savings. Results have shown that for direct injected butane, hydrocarbon emissions were found to be an order of magnitude lower than for port fuel injected butane. Furthermore, the experiments have shown that carbon monoxide and nitrogen oxides are not negatively affected compared to the diesel baseline. At a butane mass fraction of one-third and a 8 bar IMEP load point, smoke emissions decreased by $50 \%$. Because a high combustion efficiency is retained, fuel cost savings can be significant, at more than 6 percent (at current Dutch price and tax levels). At higher loads (12 bar IMEP), even more butane can be added to the directly injected blend, without negatively affecting emissions, which enables even larger cost savings.

The next research step might be to use LPG instead of butane. However, this needs some extra attention for the engine setup. Next to changing the fuel, one should show the maximum allowable butane content at higher loads and possibly more representative operating conditions (i.e. with use of EGR). One of the challenges using LPG in the proposed concept can be cold start ignitability, because of its lower reactivity compared to diesel. Finally, the good indicated efficiency and fairly low emissions of $\mathrm{NO}_{\mathrm{x}}, \mathrm{HC}$ and $\mathrm{CO}$ shown, altogether form a good reason to further explore the proposed strategy of pre-mixed direct injection of LPG and diesel.

\section{REFERENCES}

1. Donghui, Q., Longbao, Z., and Shenghua, L., "Experimental studies on the combustion characteristics and performance of a naturally aspirated, direct injection engine fuelled with a liquid petroleum gas/diesel blend," Proc. 
IMechE. Part D: J. Automobile Engineering, 219(2): 253-261, 2005, doi: 10.1243/095440705X5920.

2. Jian, D., Xiaohong, G., Gesheng, L., and Xintang, Z., "Study on Diesel-LPG Dual Fuel Engines," SAE Technical Paper 2001-01-3679, 2001, doi:10.4271/2001-01-3679.

3. Poonia, M., Ramesh, A., and Gaur, R., "Experimental Investigation of the Factors Affecting the Performance of a LPG - Diesel Dual Fuel Engine," SAE Technical Paper 1999-01-1123, 1999, doi:10.4271/1999-01-1123.

4. Cao, J., Bian, Y., Qi, D., Cheng, Q., and Wu, T., Comparative investigation between diesel and mixed liquefied petroleum gas/diesel injection engines.," Proc. IMechE. Part D: J. Automobile Engineering, 218(5):557-565, 2004, doi: $\underline{10.1243 / 095440704774061219}$.

5. Leermakers, C., Luijten, C., Somers, L., Kalghatgi, G. et al., "Experimental Study of Fuel Composition Impact on PCCI Combustion in a Heavy-Duty Diesel Engine," SAE Technical Paper 2011-01-1351, 2011, doi: 10.4271/2011-01-1351.

6. Younglove, B., and Ely, J., "Thermophysical properties of fluids. II. Methane, ethane, propane, isobutane, and normal butane," J. Phys. Chem. Ref. Data 16:577-798, 1987, doi: $10.1063 / 1.555785$.

7. Thompson, G., and Larsen, A., "DIPPR: Satisfying Industry Data Needs,” J. Chem. Eng. Data, 41(5):930-934, 1996, doi: 10.1021/je960014d.

8. Kalghatgi, G., "Auto-Ignition Quality of Practical Fuels and Implications for Fuel Requirements of Future SI and HCCI Engines," SAE Technical Paper 2005-01-0239, 2005, doi:10.4271/2005-01-0239.

9. Guggenheim, E., "The theoretical basis of Raoult's law," Trans. Faraday Soc., 33:151-156, 1937, doi: 10.1039/ TF9373300151.

10. Hildingsson, L., Kalghatgi, G., Tait, N., Johansson, B. et al., "Fuel Octane Effects in the Partially Premixed Combustion Regime in Compression Ignition Engines," SAE Technical Paper 2009-01-2648, 2009, doi:

$10.4271 / 2009-01-2648$.

\section{CONTACT INFORMATION}

C.A.J. Leermakers

Combustion Technology

Department of Mechanical Engineering

Eindhoven University of Technology

P.O. Box 513, WH 3.136

5600 MB Eindhoven

The Netherlands

$\mathrm{T}+31402472393$

$\mathrm{F}+31402433445$

C.A.J.Leermakers@tue.nl

www.combustion.tue.nl

\section{ACKNOWLEDGMENTS}

This project was funded by the Dutch Technology Foundation STW (the technical sciences division of NWO) and the Technology Programme of the Ministry of Economic Affairs. DAF Trucks N.V., Shell Global Solutions, Avantium Chemicals B.V. and Delphi are also acknowledged for their contributions to the project. The authors kindly appreciate the support of the technicians of the Eindhoven Combustion Technology group: Bart van Pinxten, Hans van Griensven, Gerard van Hout and Theo de Groot. Joep Lammerts and Rob van Berkel from Vialle are acknowledged for their help in realizing the experiments. 